\title{
An analysis of the relationship between occupational stress and employee job performance in public health care institutions: A case study of public hospitals in Harare
}

\begin{tabular}{|c|c|}
\hline \multicolumn{2}{|c|}{$\begin{array}{l}\text { Authors: } \\
\text { Tawaziwa Wushe } \\
\text { Jacob Shenje }{ }^{3} \text { (D) }\end{array}$} \\
\hline \multicolumn{2}{|c|}{$\begin{array}{l}\text { Affiliations: } \\
{ }^{1} \text { College of Economic and } \\
\text { Management Sciences, } \\
\text { University of South Africa, } \\
\text { Pretoria, South Africa }\end{array}$} \\
\hline \multicolumn{2}{|c|}{$\begin{array}{l}{ }^{2} \text { Country Cool Air } \\
\text { Conditioning Pvt Ltd, Harare, } \\
\text { Zimbabwe }\end{array}$} \\
\hline \multicolumn{2}{|c|}{$\begin{array}{l}{ }^{3} \text { Decision Point Consultants } \\
\text { Pvt Ltd, Harare, Zimbabwe }\end{array}$} \\
\hline \multicolumn{2}{|c|}{$\begin{array}{l}\text { Corresponding author: } \\
\text { Tawaziwa Wushe, } \\
\text { tawaziwa@countrycool.co.zw }\end{array}$} \\
\hline \multicolumn{2}{|c|}{$\begin{array}{l}\text { Dates: } \\
\text { Received: } 21 \text { May } 2018 \\
\text { Accepted: } 29 \text { May } 2019 \\
\text { Published: } 05 \text { Nov. } 2019\end{array}$} \\
\hline \multicolumn{2}{|c|}{$\begin{array}{l}\text { How to cite this article: } \\
\text { Wushe, T., \& Shenje, J. } \\
\text { (2019). An analysis of the } \\
\text { relationship between } \\
\text { occupational stress and } \\
\text { employee job performance in } \\
\text { public health care } \\
\text { institutions: A case study of } \\
\text { public hospitals in Harare, SA } \\
\text { Journal of Human Resource } \\
\text { Management/SA Tydskrif vir } \\
\text { Menslikehulpbronbestuur, } \\
\text { 17(0), a1079. https://doi.org/ } \\
\text { 10.4102/sajhrm.v17i0.1079 }\end{array}$} \\
\hline \multicolumn{2}{|c|}{$\begin{array}{l}\text { Copyright: } \\
\text { (C) 2019. The Authors. } \\
\text { Licensee: AOSIS. This work } \\
\text { is licensed under the } \\
\text { Creative Commons } \\
\text { Attribution License. }\end{array}$} \\
\hline \multirow{2}{*}{$\begin{array}{l}\text { Read online: } \\
\text { 口is: }\end{array}$} & \\
\hline & $\begin{array}{l}\text { Scan this QR } \\
\text { code with your } \\
\text { smart phone or } \\
\text { mobile device } \\
\text { to read online. }\end{array}$ \\
\hline
\end{tabular}

Orientation: Occupational stress has become a major challenge for employers with potentially damaging physiological and psychological effects on employees as it negatively affects their health and contribution to the effectiveness of organisations.

Research purpose: The primary purpose of the study was to investigate the relationship between occupational stress and employee job performance.

Motivation for the study: Public health care employees such as doctors, nurses, midwives and laboratory technicians had become more likely to have higher workload and inflexible working hours as they keep up with the increasing demand. Owing to shortages of staff, most of the health care employees had become stress ridden as they had to work for long working hours, face incompatible demands and find lack of support from superiors.

Research approach/design and method: A quantitative research design was adopted for the study. A structured questionnaire was developed, validated and distributed to 260 employees and management personnel working in five selected government departments.

Main findings: The study concluded that there is a negative relationship between increase in inflexibility in work hours and job performance. The findings also noted a negative relationship between work overload and job performance.

Practical/managerial implications: The data collected from this study might form part of policy-making for both the government and the management of public health care institutions. Moreover, the findings on the stress factors affecting the performance of health care workers may be used to develop strategies and provide an environment that ensures improved employee performance.

Contribution/value-add: The study is expected to enrich the empirical evidence on the stressors in public health care institutions and also provide recommendations for practitioners in investigating the relationship between occupational stress and employee job performance in the public sector

Keywords: health care institutions; job performance; public sector; occupational stress; work overload; working environment.

\section{Introduction}

\section{Orientation}

Improving the performance of employees has become the subject of great interest to human resources practitioners and academics in both developing and developed nations (Ganster \& Rosen, 2013; Velnampy, 2013; Whiting, 2016). However, occupational stress is now a major challenge for employers with potentially damaging physiological and psychological effects on employees as it negatively affects their health and contribution to the effectiveness of organisations. Consequently, the costs of occupational stress have become a huge burden on private and public sector organisations. For instance, it is estimated that globally at least 3 billion employees face serious occupational stress problems, which negatively affect the performance, and organisations have lost trillions of dollars every year (Beheshtifar \& Nazarian, 2015; Tearle, 2013; Whiting, 2016). In the same vein, studies by Shuriquie and Fitzpatrick (2015) revealed that occupational stress accounted for between $50 \%$ and $60 \%$ of all lost working days. In this regard, occupational stress 
has become a rapidly growing worldwide problem. More so, health care professionals, who spend most of their time at work, have been at risk of stress-related problems, with high rates of turnover, absenteeism and burnout (Leap-Han, 2012; Sharifah, Afiq, \& Siti, 2011).

In Zimbabwe, the public health sector had been lurching from one crisis to the other over the past two decades as the government struggled to pay employees and faced critical shortages of drugs in hospitals (Daily News, 2017). According to the World Health Organization (2008), the Zimbabwean health care system was among the best in the developing world. However, the public health care had been engulfed by poor working conditions with both doctors and nurses complaining about the poor state of hospital infrastructure. Indeed, the sector had been facing serious operational challenges, including significant shortages of drugs, painkillers and manpower such as doctors and nurses.

As noted by Zina (2017), some public hospitals in Harare had been facing unprecedented patient-doctor ratio of 1:12 000, which is high above the 1:200 prescribed by the United Nations. With government freezing all recruitments for nurses and doctors in 2015, work place pressure characterised by long working hours had been growing day by day. The shortage of staff had also resulted in vacancy rates of over $50 \%$ for doctors, midwives and laboratory staff (Tsutsumi \& Kawakami, 2014). The available health care employees in public hospitals had been contending with meagre salaries, lack of involvement in decision-making and heavy workload (Zina, 2017). Most of the health workers, including doctors, were being paid way below the poverty datum line with some getting a basic salary of \$284.00 a month (Daily News, 2017). In particular, junior doctors and nurses had been failing to make ends meet as the economic situation in the country had been deteriorating, resulting in the devaluation of their salaries. As noted by the Zimbabwe Nurses Association, public health institutions had been facing not only human resources constraints but also a lack of proper equipment and poor employee remuneration (Zina, 2017). As a result, nurses were being overworked, especially in rural areas where there had been a shortage of manpower. All in all, most of the government hospitals had been characterised by poor working conditions, inadequate bed linen and lack of protective clothing, which exposed employees to communicable diseases (Daily News, 2017). Thus, the health professionals in the public hospitals had been working under intense pressure and stress with poor salaries and a critical lack of supplies. As a result, it had become impossible for these professionals to do what they are supposed to do. Owing to shortages of staff, most of the health care employees had become stress ridden as they had to work for long working hours and face incompatible demands and lack of support from superiors. For instance, most of the health care workers such as nurses and midwives sometimes would be on 24-hours duty, and the physical and psychological demands of their duties and responsibilities make them more vulnerable to high levels of workplace stress. The results of these stressors had been inefficiency as amplified by errors in prescriptions, lack of team work, staff turnover, numerous patients' complaints, injuries and absenteeism (Faraji, Ramazani, \& Hedaiati, 2015).

It should also be noted that there is dearth of literature on the impact of occupational stress on employee performance in the context of public health services sector in Zimbabwe that can be utilised. Majority of the studies have focused on American, European and Asian countries with a huge gap existing in developing countries such as Zimbabwe (AlMalki, Fitzgerald, \& Clark, 2011; Tsutsumi \& Kawakami, 2014; Vanishree, 2014). Therefore, it was imperative to investigate the relationship between occupational stress and employees' productivity in Zimbabwe's public health care sector with particular reference to public hospitals in Harare.

\section{Research purpose and objectives}

Public health care employees such as doctors, nurses, midwives and laboratory technicians had become more likely to have higher workload and inflexible working hours as they keep up with the increasing demand. The primary purpose of the study was to investigate the relationship between occupational stress and employee job performance. The specific objectives for the study included the following:

- Establish the relationship between increase in inflexibility in work hours and employee job performance.

- Determine the association between work overload and employee job performance.

- Establish the relationship between working environment and employee job performance.

\section{Literature review}

\section{Definitions of occupational stress}

Occupational stress is a robust term that means various types of both physiological and psychological pressures that are felt and handled by employees at workplace. According to Abebe and Alemseged (2016), occupational stress includes physical or emotional factors resulting in bodily and mental imbalances of employees at the workplace. Similarly, Desa, Yusooff, Ibrahim and Kadir (2014) define occupational stress as a condition of physical and psychological mental disorder that results from pressure. For Nwokeocha (2015), occupational stress can be described as the response that employees experience when they face work demands and pressures beyond their knowledge, skills and abilities. As for Rizwan, Waseem and Bukhari (2014), occupational stress involves reactions to various psychological and physical demands encountered by employees. The above definitions are largely restricted to the work environment and are triggered by work-related aspects.

It should be noted that occupational stress is now a vital issue for every organisation because of its tendency to contribute towards employee inefficiency, absenteeism, turnover 
intentions and decreased job satisfaction. This is eluded by Al-Malki et al. (2011) and Vanishree (2014) who argue that occupational stress has become a daunting challenge for employers because of its association with low employee productivity, increased absenteeism and other problems such as drug abuse, hypertension and other cardiovascular problems. Employees in various work places experience various levels of stress. For instance, there are occupations where employees have to display emotions such as nursing, social work and teaching (Hsu, Huang, \& Huang, 2015). Employees need a working environment where there is minimal distraction and where concentration will improve.

\section{Transactional stress model}

The transactional stress model by Lazarus and Folkman (1984) has been influential in theorising studies on the impact of occupational stress on employee job performance. The theory assumes that cognitive appraisals have an important role to play role in the stress process of employees. The transactional model of stress arises from the estimation that some particular environmental demands are about to wear out individual resources and energy, thereby threatening individual's well-being (Faraji et al., 2015; Ramos, Alés, \& Sierra, 2014). This appraisal process involves an individual's evaluation of a given encounter with respect to his or her well-being. These encounters can be categorised as benignpositive, irrelevant and stressful (Truxillo, Cadiz, Rineer, Zaniboni, \& Fraccaroli, 2012). On the basis of these appraisals, employees within an organisation can start coping processes, and this in turn stimulates reappraisal processes. The theory also argues that power and authority of the transaction would depend on the appraisal that binds the person and the environment.

\section{Sources of occupational stress}

Sources of occupational stress experienced by employees may differ from country to country and from each individual or group of employees, depending on personality, skills and circumstances (Harzer \& Ruch, 2015; Ijaz \& Khan, 2015). Moreover, there are some jobs that produce more stress than others, and the broad sources of occupational stress include work relationships, organisational factors, personal factors and job characteristics (Celik, 2013; Malik \& Noreen, 2015). The organisational factors that cause stress include organisational structure and culture, management styles and career development. In the context of job characteristics, the causes of stress include intrinsic job demands, that is, if the nature of the job is repetitive, insufficient challenge or excessive job for one person and degree of autonomy. Others are role conflict, that is, organisations' expectations lead to confusion or do not meet job holders' expectations and contractual terms. The main causes of stress include long working hours, management styles, poor salary packages and non-work factors such as relationships with family and workplace associates. Additionally, Aliya, Maiya, Farah and Hina (2015) point out that job security is considered as the more common cause of occupational stress in the public sector. More so, it should be noted that occupational stress affects both employees and the organisations in terms of monetary and non-monetary costs (Joy \& Radhakrishnan, 2013).

There has been an increasing support for the argument that the role of employees in the organisation may initiate conditions that trigger stress for employees at work, thereby affecting the quality of work life. Indeed, work overload is viewed as an important determinant that causes stress in the work settings. According to Shah and Hasnu (2013), work overload comprises heavy assignment of tasks, unreachable deadlines as well as long working hours. Ya lıo lu, Karagülle and Baran (2014) argue that work overload happens when employees feel pressure on themselves and the demands of a situation would be larger than they can handle. Findings by Uriena, Oscab and Salmonesc (2016) from Mexico and Spain studies showed that if employees had lumber on their minds, they felt stress, ultimately dissipating their productivity level. Another study by Amponsah-Tawiah and Mensah (2016) from the Ghanaian mining industry also identified a negative relationship between employee performance and work overload. Sabherwal, Ahuja, George and Handa (2015) tested the relationship between work stressors such as workload pressure and job performance among faculty members in higher education institutions in Pune and concluded that workload pressure had a negative effect on job performance. Similarly, Bojke (2015) found that both qualitative and quantitative work overload were responsible for decreasing the performance of the English National Health Service employees. Zafar, Ali, Hameed and Younas (2015) too found a negative correlation between work overload and job performance among employees in Pakistan. Furthermore, a cross-sectional study (Gholamzadeh, Sharif, \& Rad 2016) among nurses working in Admission and Emergency Department in hospitals affiliated to Shiraz University of Medical Sciences, Iran, concluded that workload and inadequate monitory rewards were the prime reasons of causing stress in employees that led to reduced employee efficiency. A cross-sectional study on stress and its associated factors among ward nurses of Kuala Lumpur Public Hospital found that employees faced many expectations from direct boss, subordinates, colleagues and top management. The results of structural equation modelling on Universities of Peshawar by Hashim, Khattak and Kee (2017) also suggested that employees who had heavy workloads were unable to establish a balance between work and family roles and displayed a poor performance in the service delivery process.

An efficiently operated and carefully enforced comprehensive workplace flexibility programme can be a winning situation for both employees and employers. Among the benefits to employers are improved work engagement, better recruitment outcomes and workforce retention, and enhanced productivity. Such gains provide a competitive edge for any organisation. On the other hand, the benefits of workplace flexibility programmes to employees include reduced stress on the job, better work/family and work/life 
balance, and improved physical and mental health (Hashim \& Hameed, 2012). Having flexible working hours means employees can plan their everyday life in terms of social integration with family members and leisure activities. This phenomenon can be explained by the social exchange theory, which posits that human relationships are formed by using a subjective cost-benefit analysis and the comparison of alternatives (Vanishree, 2014).

It has also been noted by different scholars that increased inflexibility in working hours negatively affect employee job performance. Inflexibility in work hours distorts the physical and mental health of an individual, which negatively affects the employees' productivity. A study by Amyx, Sharma and Alford (2014) in the United Kingdom on salesperson performance and commitment indicated that the majority of employees were not happy with the current work culture, where they had to work extended hours and cope with inflexible working hours and deadlines. Studies by Mehta and Singh (2015) on nurses working in critical care areas at a tertiary care teaching hospital, Nepal, discovered that inflexible working hours had a negative impact on employee performance, leading to job dissatisfaction, decreased employees' morale and increased job turnover. In addition, the study by Rizwan et al. (2014) showed a negative relationship between inflexible working hours and employee job performance. On the other hand, Suwati and Gagah (2016) found that people working on inflexible hours showed health issues, more physiological disturbance and problems in sleep. Furthermore, Frimpong, Helleringer and Phillips (2011) conducted a research on the time and workplace flexibility among health workers from the Upper East Region of Ghana. The study found that inflexible working hours had a negative relationship with employee performance, job satisfaction and work performance.

The working environment is regarded as one of the most important resources of occupational stress. It consists of safety to employees, job security, good relations with coworkers, recognition for good performance and motivation for good performance (Tahir et al., 2014). Factors relating to the workplace, such as the quality of air, noise level and working relationship, can lead to the quality of working environment. Other factors within the working environment such as wages, working hours, organisational structure and communication between employees and management also affect job performance (Naharuddin \& Sadegi, 2013). Organisations need to understand that their employees spend almost a day at work and that is the reason why they need to make sure working environment is conducive for employees to be productive, satisfied and engaged in the workplace.

It should be elaborated that once employees realise that an organisation considers them important, they will have high level of commitment and a sense of ownership for that organisation. Cavalheiro and Moura (2008) explain that if employees are dissatisfied with their working environment, they tend to do their work very slowly and this directly affects the performance and overall productivity of the organisation. An exploratory study by Okoyo and Ezejiofor (2013) showed that working environment variables such as social support had a direct impact on job satisfaction and job performance among employees. The study also revealed that with good and effective supervision, employees' performance level was high. In the same vein, another study by Cavalheiro and Moura (2008) on the job performance level among nurses working in intensive care units showed that if proper attention was given towards interpersonal relationships, recognition and supervision, the level of job performance would rise. Similarly, Abebe and Alemseged (2016) found that employees who worked under difficult working conditions were generally dissatisfied.

\section{Empirical studies}

There are various empirical studies that have been conducted to examine the relationship between occupational stress and job performance. A quantitative study by Hasan, Batool and Fatima (2015) among private and government school teachers concluded that there was a negative and significant relationship between occupational stress and employee job productivity. Another study by Ramos et al. (2014) among Spanish workers also revealed that there was a significant negative relationship between occupational stress and job performance. Similarly, another study conducted by Olaleye and Arogundade (2013) on university administrators in South West Nigeria found a negative relationship between occupational stress and job performance. In corroboration, Ijaz and Khan (2015) also noted that higher turnover rates and the propensity to leave had been associated with job dissatisfaction. Zafar et al. (2015) analysed the impact of job stress on employee performance in the industrial sector of Pakistan, and it was found that the presence of job-related stress can have negative impacts either on the employees or on the organisation.

As expounded by Gatchel and Schultz (2012), occupational stress results in low job performance because of its psychological and financial importance to both the employees and employers. Studies by Ali, Hassan, Ali and Bashir (2013) also revealed that occupation stress deposited adverse relationship on job attitudes, self-confidence, dissatisfaction with life and the upswing in turnover intentions. In agreement, Fajana et al. (2011) noted that there was an undesirable correlation between occupational stress and job performance. This was also established by Shuriquie, While and Fitzpatrick (2015) in their studies on medical colleges who argued that anxiety, low self-esteem and motivation, mood variations declined the job performance and job satisfaction.

Sims and Sun (2012) also found a positive relationship between organisational stress and turnover intention. Studies on the impact of organisational stress on employee turnover intention have shown surprisingly very little consistency in findings, which may be because of the diversity of employees. 
Thus, it may be argued that there are many reasons why people voluntarily quit from one organisation to another or why people choose to leave the organisation. In a metaanalysis study, Muchhal (2014) found that high amount of occupational stress led to dissatisfaction with the job and low job performance. This deprived situation provided a favourable environment for turnover intentions among the employees. Another research by Assaf and Alswalha (2013) revealed the negative association between job satisfaction and poor physical health, low psychological well-being and high level of occupational stress. A study by Hasan, Batool and Fatima (2015) also highlighted the significant link between occupational stress and its contrary reactions such as sleep disorders, psychological problems, heart disease and low level of job performance, job satisfaction and rising turnover intentions.

\section{Conceptual framework}

On the basis of the above literature, a conceptual framework has been proposed that consists of the identified occupational stress elements discussed and job performance. These include increase in inflexibility in work hours, work overload and working environment. These elements appear most in the literature, are embedded within the robust occupational stress context in the public health care sector and are relatively essential in determining employee job performance. Thus, the occupational stress elements in this study are measured as multi-dimensional construct whereby occupational stress is the proxy for employee job performance. Figure 1 illustrates the study's conceptual framework.

\section{Methodology \\ Research design}

A descriptive research design was used in collecting primary data from the respondents. Descriptive research design was preferred because of its ability to answer questions such as who, how, what, which, when and how much (Zikmund et al., 2013). More so, a descriptive research design ensured complete description of the situation, making sure that there was minimum bias in the collection of data and reduced errors in the interpretation of data (Easterby-Smith, Thorpe, \& Jackson, 2012).

Moreover, this is a quantitative study as it sought to find answers to questions through analysis of numerical data.

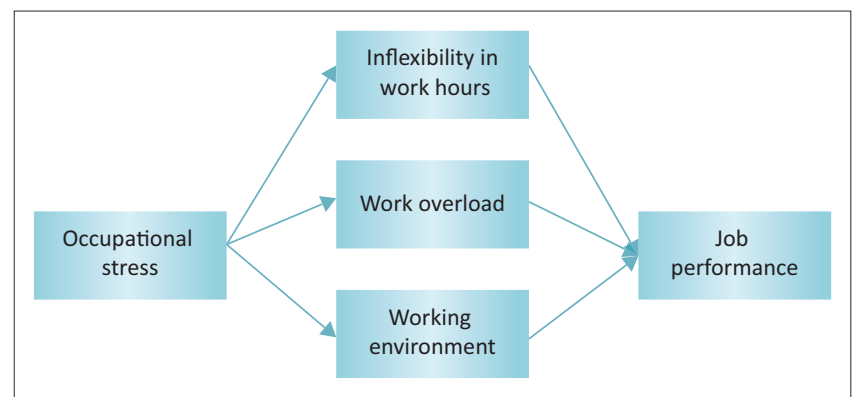

FIGURE 1: Conceptual framework.
Furthermore, the study used a quantitative research approach as it sought to measure variables and express any relationships between independent and dependent variables using inferential statistics such as correlations and regressions (Fowler, 2013). The other purpose of a quantitative research approach was to collect primary numeric data and could be analysed using statistical techniques.

\section{Population and sample size}

The study's population consisted of health care employees and management personnel from three public hospitals in Harare. These included nurses, doctors, midwives, laboratory technicians and nursing assistants. A total of 400 participants were randomly selected from the three main public hospitals in Harare. It was expected that meaningful data pertaining to the relationship between occupational stress and job performance could be extracted from the population. Because it was not possible to cover all the participants in the population, it was important to determine a sample size for the study. The sample size was calculated using the following statistical formula:

$$
\begin{aligned}
& n=400 / 1+\left(400 * 0.05^{2}\right) \\
& n=197
\end{aligned}
$$

[Eqn 1]

Using the above formula, a population of 400 participants would statistically require a sample size of 197 participants at $5 \%$ level of significance.

\section{Sampling techniques}

Probability sampling techniques were used in the study. In particular, stratified sampling was used to pick the study respondents from the three public hospitals. This consisted of splintering the target population into a series of various relevant strata and that made the sample representative (Forbat \& Henderson, 2012). Because the sample was divided into five strata, stratified sampling was found to be the most appropriate technique for selecting the participants from various professional hospitals. The allocation of each stratum was done using proportional sampling, and the findings are shown in Table 1.

Within each identified stratum, simple random sampling technique was then adopted. The advantage of simple random sampling was that it could protect the survey research strategy from selection bias by randomly picking

TABLE 1: Proportional sampling

\begin{tabular}{lc}
\hline Sample & Stratified sampling $\mathbf{n i}=\boldsymbol{n}^{*} \mathbf{N i} / \mathbf{N}$ \\
\hline Doctors & 38 \\
Nurses & 44 \\
Nursing assistants & 46 \\
Midwives & 34 \\
Laboratory technicians & 35 \\
\hline Total & $\mathbf{1 9 7}$ \\
\hline
\end{tabular}

$\mathrm{Ni}$, sample size; $\mathrm{Ni}$, Number of sampling units in the strata; $\mathrm{N}$, population size. 
the sample with equal probability to any other possible sample (Mugenda \& Mugenda, 2009).

\section{Research instrument}

Structured questionnaires were used as the research instrument for gathering information that would produce desirable and reliable results from the respondents. Questionnaires provided irreplaceable ways of determining attitudes, opinions and perceptions of individual behaviour for the study respondents. Besides that, the use of questionnaire allowed the researchers to gather standardised and objective results. The questionnaire consisted of the first section, which extracted demographic data from the respondents such as age, gender, level of education, position and years of experience. The other sections focused on the relationship between increase in inflexibility in work hours and employee job performance, the association between work overload and employee job performance and the relationship between working environment and employee job performance.

The study variables were measured using 5-point Likert scale. This comprised several statements and questions designed to examine how strongly the subjects agreed or disagreed towards it. The 5-point Likert scale was chosen because it facilitated robust statistical analysis, and responses were gathered in a standardised way. Questions relating to occupational stress were measured using the NIOSH Generic Job Stress Questionnaire (Faraji et al., 2015; Shuriquie et al., 2015) and MBI-Human Services Survey covering personal burnout and work-related burnout as two dimensions of burnout (Rees \& Freeman, 2009). On the other hand, employee job performance was measured using organisational performance scale by Mulki, Jaramillo, Goad and Pesquera (2014).

The questionnaire was first pretested before distribution to the respondents. The pilot test of the questionnaire provided the researcher the opportunity to gather information and test for logic prior to the actual sample, in order to improve its quality and efficiency (Cohen \& Marion, 2011; Krishnaswami \& Ranganatham, 2009). The pilot study also provided the researcher with the way information should be gathered. For this study, a total of 10 respondents were randomly selected from the sample.

The internal consistency of the research instrument was measured by calculating Cronbach's alpha to determine general reliability. According to Kock and Lynn (2012), the closer the Cronbach's alpha is to 1, the higher will be the internal consistency reliability. As suggested by Hair (2015), if the reliability is less than 0.60 , it is considered as poor; if it is in the range of 0.70 , it is considered as acceptable; and if it is more than 0.80, it is considered as good. The following table shows the Cronbach's alpha values for the study variables (Table 2).

From Table 2, the Cronbach's alpha for job performance is 0.837; for working environment, it is 0.811 ; for work overload,
TABLE 2: Reliability test.

\begin{tabular}{lcc}
\hline Construct & Number of items & Cronbach's coefficient \\
\hline Inflexibility in working hours & 7 & 0.820 \\
Work overload & 10 & 0.851 \\
Working environment & 6 & 0.811 \\
Job performance & 5 & 0.837 \\
\hline
\end{tabular}

it is 0.851; and for inflexibility in work hours, it is 0.820 . Accordingly, the study variables can be considered good and extremely reliable as they have Cronbach's coefficients more than 0.8 .

\section{Research procedure and ethical considerations}

Permission was sought from the management of the selected hospitals to conduct this survey. In addition, the researchers sought permission and written consent from all study participants. The researchers administered the questionnaires through the use of drop and pick method. The benefit of the drop and pick method was that respondents were given enough time to answer the questionnaire. As such, that resulted in significantly higher response rates. All the questionnaires distributed were accompanied with cover letter, which assured confidentiality of data and anonymity of respondents. The cover letter also explained the purpose of the study. All study respondents were assured that the primary data obtained from the study would be kept confidential, and hence, they could feel confident to express their opinion without fear and concern. The researchers also ensured that anonymity of the participants was maintained through the removal of any identifying characteristics before the dissemination of information. It was also assured that all collected data would be analysed and reported only in aggregate form.

\section{Data analysis}

The process of primary data analysis includes inspecting, cleaning and modelling in order to have information to draw conclusions and suggest necessary recommendations. Statistical Package for the Social Sciences (SPSS) version 25.0 was used to duly analyse the collected data. The software program was used to create data sheet for further statistical analysis. Descriptive statistics in the form of frequency and percentages were used to summarise and organise the data, and inferential statistics were used to investigate the relationship between occupational stress and employee job performance. Means and standard deviations were calculated for various dimensions of total quality management practices constructs. For analysis of the entire study, both correlation and regression analyses were used to establish the degree of relationship between occupational stress and employee job performance. Correlation coefficient was used to measure relationships among various occupational stress variables and employee job performance at $95 \%$ confidence level. In order to know the most contributory of this relationship between the variables, the multiple regressions were conducted to predict the variance 
in a single dependent variable. In other words, multiple regression analysis was used to specify the most crucial variables for the relationship between occupational stress and employee job performance.

\section{Ethical considerations}

The ethical considerations conserved in the study included anonymity of respondents, confidentiality of primary data as well as seeking permission to conduct research from relevant authorities such as the Ministry of Health and Child Welfare as well as the management of the respective public hospitals.

\section{Results}

A total of 197 structured questionnaires were distributed by the researchers, of which 167 questionnaires were returned, and these formed the basis for further data analysis. The returned questionnaires represented a response rate of $84.8 \%$. Table 3 shows the study's response rate.

From the findings above, the response rate of $84.8 \%$ was considered high enough to produce valid expressions of opinion and satisfactorily generalise the results to the population. Moreover, the high response was in line with Hair, Hult, Ringle and Sarstedt (2014) who recommend that a response rate above $70 \%$ is regarded as excellent and adequate for statistical data analysis.

The study tested the distribution of the sample data set using Kolmogorov-Smirnov and Shapiro-Wilk tests. Both the Kolmogorov-Smirnov test and Shapiro-Wilk test are arguably the most well-known non-parametric test of goodness of fit for the continuous cumulative distribution of given data samples (Bryman \& Bell, 2015). More so, because the sample size was more than 50 respondents, the study used the Kolmogorov-Smirnov test in line with recommendations by Kakkuri-Knuuttila (2008) and Sullivan (2011). The findings are tabulated in Table 4.

\begin{tabular}{lccc} 
TABLE 3: Response rate. & $\begin{array}{c}\text { Distributed } \\
\text { Sample }\end{array}$ & $\begin{array}{c}\text { Returned } \\
\text { questionnaires }\end{array}$ & $\begin{array}{c}\text { Response } \\
\text { rate (\%) }\end{array}$ \\
\hline Doctors & 38 & 29 & 76.3 \\
Nurses & 44 & 40 & 90.9 \\
Nursing assistants & 46 & 41 & 89.1 \\
Midwives & 34 & 29 & 85.3 \\
Laboratory technicians & 35 & 28 & 80.0 \\
\hline Total & $\mathbf{1 9 7}$ & $\mathbf{1 6 7}$ & $\mathbf{8 4 . 8}$
\end{tabular}

From the Kolmogorov-Smirnov test results in Table 4, it has been indicated that the study variables were normally distributed. In particular, the total score of increase in inflexibility in work hours, work overload and working environment scales has the normal distribution because their respective significance levels are higher than 0.05. Moreover, the significant values of the Shapiro-Wilk test were above 0.05 and this means that the data were a normal distribution. If significant values of the Shapiro-Wilk test were below 0.05, then the data would have significantly deviated from a normal distribution.

The study first determined the demographic characteristics of the respondents in order to determine the suitability of the respondents in providing the required information for the validity of the study. This was also done in order to make a basis of making conclusions on the views that respondents provided on the impact of occupational stress on job performance. From the findings, it was found that majority were females (53\%), and the average age category for the respondents was 31 years to 40 years (44\%). In addition, majority of the respondents (95\%) had been with their respective institutions for a period of at least 6 years. In terms of educational qualifications, most of the respondents had at least a professional diploma. Table 5 summarises the demographic characteristics of the respondents.

Descriptive statistics were used to show the validity of the research constructs. In particular, mean and standard deviations were used to measure central tendency and dispersion, respectively. The findings are tabulated in Table 6.

TABLE 5: Demographic characteristics of the respondents.

\begin{tabular}{lll}
\hline Demographic variable & Category & Valid per cent \\
\hline Age of respondents & 20 years to 30 years & 26 \\
& 31 years to 40 years & 44 \\
& 41 years to 50 years & 17 \\
& 51 years and above & 13 \\
Gender of respondents & Male & 47 \\
& Female & 53 \\
Level of education & Diploma & 48 \\
& Undergraduate degree & 31 \\
& Master's degree & 21 \\
Working experience & Doctorate degree & - \\
& 1 year to 5 years & 5 \\
& 6 years to 10 years & 51 \\
& 11 years to 15 years & 33 \\
& Above 15 years & 11 \\
\hline
\end{tabular}

TABLE 4: Kolmogorov-Smirnov test and Shapiro-Wilk test of normality.

\begin{tabular}{|c|c|c|c|c|c|c|}
\hline \multirow[t]{2}{*}{ Job performance } & \multicolumn{3}{|c|}{ Kolmogorov-Smirnov $\dagger$} & \multicolumn{3}{|c|}{ Shapiro-Wilk } \\
\hline & Statistic & Degree of freedom & Significance & Statistic & Degree of freedom & Significance \\
\hline \multicolumn{7}{|l|}{ Occupational stress } \\
\hline $\begin{array}{l}\text { Increase in flexibility in } \\
\text { work hours }\end{array}$ & 0.32 & 13 & 0.16 & 0.68 & 6 & 0.81 \\
\hline Work overload & 0.27 & 24 & 0.20 & 0.79 & 21 & 0.84 \\
\hline Working environment & 0.18 & 26 & 0.19 & 0.79 & 25 & 0.87 \\
\hline
\end{tabular}

$\dagger$, Lilliefors significance correction. 
TABLE 6: Descriptive means and standard deviations.

\begin{tabular}{lccc}
\hline VaBLiable & $\boldsymbol{N}$ & Mean & Standard deviation \\
\hline Inflexible working hours & 167 & 3.61 & 0.68 \\
Work overload & 167 & 3.95 & 0.41 \\
Working environment & 167 & 3.32 & 0.96 \\
Job performance & 167 & 3.19 & 0.79 \\
\hline
\end{tabular}

TABLE 7: Correlation analysis.

\begin{tabular}{lcccc}
\hline Variable & $\mathbf{1}$ & $\mathbf{2}$ & $\mathbf{3}$ & $\mathbf{4}$ \\
\hline Increase in flexibility in working hours & 1.00 & - & - & - \\
Work overload & $-0.67^{* *}$ & 1.00 & - & - \\
Working environment & $-0.56^{* *}$ & $-0.34^{*}$ & 1.00 & - \\
Job performance & $-0.03^{*}$ & $-0.37^{* *}$ & $0.79 *$ & 1.00
\end{tabular}

$*$, Correlation is significant at the 0.05 level (two tailed); $* *$, correlation is significant at the 0.01 level (two tailed).

From Table 6, the mean statistics of work overload ( $m=3.947$; standard deviation $[\mathrm{SD}]=0.405)$ was the highest, which indicated that the participants viewed work overload as greatly affecting their performance at work. Moreover, this indicates that work overload can result in both physical and mental stress, which then affects employee performance. The second highest mean score was from inflexible working hours $(m=3.612 ; \mathrm{SD}=0.681)$. The findings do show that inflexible working hours is also perceived as another area of concern by the respondents after work overload.

In order to determine the relationship between occupational stress and job performance, Pearson's correlation analysis was used. Table 7 represents the result of Pearson's correlation (r), which shows the relationship between the independent variables (increase in inflexibility in work hours, work overload and working environment) and dependent variable (job performance).

Results from Table 7 reveal that there is a negative relationship between increase in inflexibility in work hours and job performance $(r=-0.03, p>0.05)$. This implies that increase in inflexibility in work hours has an inverse effect on job performance at the selected public hospitals. These findings support the studies by Amyx, Sharma and Alford (2014) in the United Kingdom on salesperson performance and commitment, which indicated that the majority of employees were not happy with the current work culture, where they had to work extended hours and cope with inflexible working hours and deadlines. In addition, the findings concur with studies by Mehta and Singh (2015) on nurses working in critical care areas at a tertiary care teaching hospital, Nepal, which concluded that inflexible working hours had a negative impact on employee performance, leading to job dissatisfaction, decreased employees' morale and increased job turnover. In addition, the study by Rizwan et al. (2014) showed a negative relationship between inflexible working hours and employee job performance.

The findings also disclosed a negative relationship between work overload and job performance $(r=-0.37-, p>0.01)$, thus implying that work overload as an occupation stressor negatively influences employee job performance at the
TABLE 8: Model summary.

\begin{tabular}{|c|c|c|c|c|}
\hline Model & $\boldsymbol{R}$ & $R^{2}$ & Adjusted $R^{2}$ & Std. error of the estimate \\
\hline 1 & $-0.512 \dagger$ & 0.108 & 0.061 & 0.64163 \\
\hline
\end{tabular}

selected public hospitals in Harare. The negative link between work overload and employees' productivity is also supported by Bojke (2015), who found that both qualitative and quantitative work overload were responsible for decreasing the performance of the English National Health Service employees. The findings also agree with a study by Zafar et al. (2015), which found a negative correlation between work overload and job performance among employees in Pakistan. Furthermore, the study findings are in line with a crosssectional study by Gholamzadeh et al. (2016) among nurses working in Admission and Emergency Department in hospitals affiliated to Shiraz University of Medical Sciences, Iran, which concluded that workload and inadequate monitory rewards were the prime reasons for causing stress in employees that led to reduced employee efficiency.

The findings also revealed a significant positive relationship between working environment and job performance $(r=0.79, p<0.05)$, which indicates that any improvement in working environment conditions would positively affect employee job performance at the public hospitals in Harare. These findings are supported by Cavalheiro and Moura's (2008) study on the job performance level among nurses working in intensive care units which revealed that if proper attention was given towards interpersonal relationships, recognition and supervision, the level of job performance would rise. Similarly, the study findings agree with Bahrami, Barati and Ghoroghchian (2016), which indicated that workplace environmental elements such as sufficient light, absence of noise, proper ventilation and layout arrangement substantially increased employee performance and productivity.

Regression analysis was performed to identify the predictors of job performance as conceptualised in the model. According to Fapohunda (2012:108), regression analysis relates one dependent variable to a linear combination of independent variables. As such, regression sought to identify how much each independent variable has an impact on the dependent variable, and this is indicated in Table 8.

In Table $8, R^{2}$ of 0.108 indicates that $10.8 \%$ of variation in employee performance is explained by the variation in the study's independent variables. The percentage is good enough to determine the goodness of fit for the model. After taking into consideration the number of predictor variables in the model, the adjusted $R^{2}$ yielded a $6.1 \%$ variation. This indicates that $6.1 \%$ of the changes on employee job performance could be attributed to the combined effect of the predictor variables of increase in inflexibility in work hours, work overload and working environment. These findings 
TABLE 9: Multiple regression analysis.

\begin{tabular}{|c|c|c|c|c|c|}
\hline \multirow[t]{3}{*}{ Model 1} & \multicolumn{3}{|c|}{ Coefficients $\dagger$} & \multirow[t]{3}{*}{$t$} & \multirow[t]{3}{*}{ Sig. } \\
\hline & \multicolumn{2}{|c|}{ Unstandardised coefficients } & \multirow{2}{*}{$\begin{array}{c}\begin{array}{c}\text { Standardised } \\
\text { coefficients }\end{array} \\
\text { Beta }\end{array}$} & & \\
\hline & $B$ & Std. error & & & \\
\hline (Constant) & 3.89 & 0.92 & - & 4.22 & 0.00 \\
\hline $\begin{array}{l}\text { Increase in } \\
\text { inflexibility in } \\
\text { work hours }\end{array}$ & -0.28 & 0.23 & -0.21 & -1.26 & 0.22 \\
\hline $\begin{array}{l}\text { Working } \\
\text { environment }\end{array}$ & 0.67 & 0.10 & 0.73 & 5.67 & 0.00 \\
\hline Work overload & -0.49 & 0.29 & -0.05 & -0.30 & 0.76 \\
\hline
\end{tabular}

Std. error, standard error; Sig., significance.

$\dagger$, Dependent variable: Job performance.

agree with a study by Ramos et al. (2014) among Spanish workers, which revealed that there was a significant negative relationship between occupational stress and job performance. Similarly, the findings support another study conducted by Olaleye and Arogundade (2013) on university administrators in South-West Nigeria, which revealed a negative relationship between occupational stress and job performance. Finally, the study findings corroborate Ijaz and Khan (2015), who also noted that the impact of occupational stress on employee performance in the industrial sector of Pakistan was negative and significant.

Multiple regression model was also used to simultaneously analyse the effect of different occupational stress variables on the independent variable of job performance. The results are listed in Table 9.

Table 9 shows the variation in dependent variable owing to each proxy of independent variable. Increase in inflexibility in work hours causes $-0.28 \%$ or $28 \%$ negative variation in employees' job performance at the public hospitals in Harare. Likewise, the study showed that work overload causes -0.49 or $49 \%$ negative variation in employee job performance at the public hospitals in Harare. Further, the findings show that a unit increase in working environment would lead to a $0.67 \%$ or $67 \%$ positive increase in employee job performance at the public hospitals in Harare. Overall, working environment had the highest effect on the employee performance, whilst the other factors under study had negative effect on employee job performance. This is pointed out by Liu, Pan, Wen, Chen and Lin (2010) in their study, which indicated that increase in both inflexibility in work hours and work overload has a negative effect on employees' productivity, which supports the results of this study. Furthermore, Nwokeocha (2015) elucidates that inflexible working hours are negatively associated with the employees' productivity, which supports the validity of these results.

\section{Discussion}

\section{Practical implications}

The study sought to investigate the relationship between occupational stress in Zimbabwean public health care institutions and its contribution to the performance of employees. The data collected from this study might form part of policy-making for both the government and the management of public health care institutions. Moreover, the findings on the stress factors affecting the performance of health care workers may be used to develop strategies and provide an environment that ensures improved employee performance. Through the study, it was found that both inflexible working hours and work overload had a negative relationship with employee job performance.

\section{Limitations and recommendations}

From the research analysis, findings and conclusions, the study recommends that public health care hospitals should redesign jobs that overwhelm employees in order to reduce workloads and spread these out evenly. Flexitime working time can also be considered by the management of public hospitals in some departments. Additionally, there is the need for better communication channels so that information reaches employees in time for better preparation instead of last-minute communication, where employees would be spending long hours at the workplace to complete various tasks. Indeed, organisational policies should be instituted that would make communication among the rank files liberalised and made easier. Cooperation among the medical doctors, lab scientists, pharmacists, nurses and other members of the medical team should be strengthened. All the public health care employees should be made to understand that they are there to complement one another for good performance and productivity.

More significantly, there is the need to conduct skills analysis and job evaluation in order to identify any staffing gaps as this will improve their performance and job satisfaction. The public hospitals should also strive to employ more workers to help lift too much workload of the workers. Furthermore, the government should enact laws that protect employees generally and health workers in particular from the menace of occupational stress, which appears to characterise present-day work organisations. The government must also provide all the facilities for employees to do their work properly with no hesitation and facilitate all the needs of employees.

The study was specifically focused on public health care hospitals in Harare only. Therefore, the findings from the study cannot be generalised to other public health care institutions outside Harare. It is suggested that future research studies many be expanded to other provinces in the country as well as other sectors such as education, other government departments, tourism, banking, to check the causes and effects of occupational stress on employees' productivity and performance. Besides the variables of occupational stress discussed in this study, it is also suggested that other researchers include more job-related stress factors such as role conflict, role ambiguity, gender discrimination, demand pressure and other factors in order to make the research more comprehensive. 


\section{Conclusion}

In determining the relationship between occupational stress and employee job performance, the study revealed that both inflexible working hours and work overload were the main factors hindering the performance of health care employees because employees reached burnout level that they could no longer produce effectively. The study concluded that that there is a negative relationship between increase in inflexibility in work hours and job performance. This implied that increase in inflexibility in work hours has an inverse effect on job performance at the selected public hospitals. The findings also concluded a negative relationship between work overload and job performance, thus implying that work overload as an occupation stressor negatively influences employee job performance at the selected public hospitals in Harare. However, the findings concluded that there was a significant positive relationship between working environment and job performance. This indicated that any improvement in working environment conditions would positively affect employee job performance at the public hospitals in Harare.

\section{Acknowledgements}

The authors would like to thank the staff at the Ministry of Health and Child Welfare for providing relevant information throughout this research.

\section{Competing interests}

The authors declare that they have no financial or personal relationships that may have inappropriately influenced them in writing this article.

\section{Authors' contributions}

The researchers worked hand in glove during the course of the study. In order to make the research more productive and efficient, J.S. formulated the research problem and synthesised relevant literature review. He was also involved in the distribution and collection of questionnaires from targeted respondents. T.W. provided the research methodology section as well as the construction of research instrument. Both authors were involved in data collation, editing and analysis. The researchers also agreed on conclusions and recommendation. After completion of the research article, T.W. was involved in proofreading for grammar and logic.

\section{Funding information}

This research received no specific grant from any funding agency in the public, commercial or not-for-profit sectors.

\section{Data availibility statement}

Data sharing is not applicable to this article as no new data were created or analysed in this study.

\section{Disclaimer}

The views and opinions expressed in this article are those of the authors and do not necessarily reflect the official policy or position of any affiliated agency of the authors.

\section{References}

Abebe, M., \& Alemseged, F. (2016). Hematologic abnormalities among children on HARRT in Jimma University Specialized Hospital South West Ethiopia. Ethiopian Journal of Health Sciences, 19(9), 83-89. https://doi.org/10.4314/ejhs. v19i2.69420

Ali, Y., \& Basher, G.D. (2013). Impact of stress on job performance: An empirical study of the employees of private sector universities of Karachi, Pakistan. Research Journal of Management Sciences, 3(7), 14-17.

Ali, M.S., Hassan, J., Ali, D.A., \& Bashir, J.N. (2013). Integrative literature review: Four emerging perspectives of employee engagement: An integrative literature review. Human Resource Development Review, 10(5), 304-328.

Al-Malki, M., Fitzgerald, G. \& Clark, M. (2011). Health care system in Saudi Arabia: An overview. Eastern Mediterranean Health Journal, 17(10), 784-793.

Amponsah-Tawiah, K., \& Mensah, J. (2016). Occupational health and safety and organizational commitment: Evidence from the Ghanaian mining industry. Safety and Health at Work, $7(3), 225-230$

Amyx, D., Sharma, H.T., \& Alford, B.L. (2014). The effects of salesperson need for achievement and sales manager leader reward behaviour. Journal of Personal Selling and Sales Management, 25(4), 345-359.

Assaf, A.M., \& Alswalha, A. (2013). Environmental impacts of working conditions in paint factories workers in the Hashemite Kingdom of Jordan, European Scientific Journal, 9(8), 66-73.

Bahrami, M.A., Barati, O., \& Ghoroghchian, M.S. (2016). Role of organizational climate in organizational commitment: The case of teaching hospitals. Osong Public Health and Research Perspectives, 7(2), 96-100.

Beheshtifar, M., \& Nazarian, R. (2015). Role of occupational stress in organizations. Interdisciplinary Journal of Contemporary Research in Business, 4(9), 648.

Bojke, C. (2015). Productivity of the English National Health Service 2003-4 to 2009-10 (pp. 1-45). CHE Research Paper 76. London: Centre for Health Economics.

Bryman, A., \& Bell, E. (2015). Business research methods. Oxford: Oxford University Press.

Cavalheiro, A.M., \& Moura, D.F. (2008). Stress in nurses working in intensive care units. Rev Latino-Americana, 16(1), 29-35. https://doi.org/10.1590/S010411692008000100005

Celik, K. (2013). The effect of role ambiguity and role conflict on performance of vice principles: The mediating role of burnout. Journal of Educational Research, 51, 195-214.

Cohen, L., \& Marion, L. (2011). Research methods in education (7th edn.). London: Routledge.

Daily News. (2017). Hospitals run out of oxygen. Retrieved from https://www. dailynews.co.zw/articles/2017/02/26/hospitals-run-out-of-oxygen.

Desa, A., Yusooff, F., Ibrahim, N., \& Kadir, N.A. (2014). A study of the relationship and influence of personality on job stress among academic administrators at a university. Procedia - Social and Behavioral Sciences, 114, 355-359. https://doi. org/10.1016/j.sbspro.2013.12.711

Easterby-Smith, M., Thorpe, R., \& Jackson, P. (2012). Management research (4th edn.). London: Pearson Education.

Faraji, O., Ramazani, A.A., \& Hedaiati, P. (2015). Relationship between job characteristics and organizational commitment: A descriptive analytical study.
Iranian Red Crescent Medical Journal, 17(11), e19815. https://doi.org/10.5812/ ircmj.19815

Fajana, M., Obisi, A., \& Oke, A. (2011): Human resource management: An introduction. Lagos: Labofin and Company.

Fapohunda, T.M. (2012). Towards improved access to full employment and decent work for women in Nigeria. International Journal of Humanities and Social Science, 2(8), 104-112.

Forbat, L., \& Henderson, J. (2012). Theoretical and practical reflections on sharing transcripts with participants. Qualitative Health Research, 15(8), 1114-1128.

Fowler, F.J. (2013). Survey research methods. New Jersey: Sage.

Frimpong, J.A., Helleringer, S., \& Phillips, J.F. (2011). Does supervision improve health worker productivity? Evidence from the Upper East Region of Ghana. Tropical Medicine \& International Health, 16(10), 1225e33. https://doi.org/10.1111/ j.1365-3156.2011.02824.x

Ganster, D.C., \& Rosen, C.C. (2013). Work stress and employee health: A multidisciplinary review. Journal of Management, 39(5), 1085-1122. https://doi. org/10.1177/0149206313475815

Gatchel, R.J., \& Schultz, I.Z. (2012). Handbook of occupational health and wellness. New York: Springer Science and Business Media.

Gholamzadeh, S., Sharif, F., \& Rad, F.D. (2016). Sources of occupational stress and coping strategies among nurses who are working in Admission and Emergency Department in hospitals affiliated to Shiraz University of Medical Sciences, Iran Iranian Journal of Nursing and Midwifery Research, 16(1), 42. 
Hair, J.F. (2015). Essentials of business research methods. London: Pearson Education Limited.

Hair, J.F., Hult, G.T.M., Ringle, C.M., \& Sarstedt, M. (2014). A primer on partial least squares structural equation modelling. Thousand Oaks, CA.

Harzer, C., \& Ruch, W. (2015). The relationships of character strengths with coping work-related stress, and job satisfaction. Frontiers in Psychology, 6, 165. https:// doi.org/10.3389/fpsyg.2015.00165

Hasan, I., Batool, T., \& Fatima, S. (2015). Life satisfaction and social support among private and government school teachers. European Journal of Business and Social Sciences, 4(8), 42-49.

Hashim, M., \& Hameed, F. (2012). Human resource management in 21st century: Issues \& challenges \& possible solutions to attain competitiveness. International Journal of Academic Research in Business and Social Sciences, 2(9), 44.

Hashim, M., Khattak, M.A., \& Kee, D.M.H. (2017). Impact of servant leadership on job satisfaction: A study of teaching faculty in universities of Peshawar. Abasyn Journal of Social Sciences, 3(7), 68-75.

Hsu, S.H., Huang, K.C., \& Huang, K.S. (2015). The relative study of social support, job satisfaction and wellbeing of military instructors - The case of high schools military instructors in Yunlin, Chiayi and Tainan districts of Taiwan. The Journal of International Management Studies, 10(1), 41-49.

Ijaz, M., \& Khan, A. (2015). The relationship of big five personality traits with job satisfaction among banking employees. Journal of Applied Environmental and Biological Sciences, 5(5), 129-138.

Joy, J., \& Radhakrishnan, D. (2013). A study on causes of work stress among tile factory workers in Kannur District in Kerala. International Journal of Scientific and Research Publications, 3(9), 13-18.

Kakkuri-Knuuttila, M.-L., (2008). Straddling between paradigms: A naturalistic philosophical case study on interpretive research in management accounting. Accounting, Organizations and Society, 33(2-3), 267-291. https://doi. org/10.1016/j.aos.2006.12.003

Kock, N., \& Lynn, G.S. (2012). Lateral collinearity and misleading results in variancebased SEM: An illustration and recommendations, Journal of the Association for Information Systems, 13(7), 11-17.

Krishnaswami, O.R., \& Ranganatham, M. (2009). Research methods. New Delhi: Himalaya Publishing House.

Lazarus, R.S., \& Folkman, S. (1984). Stress, appraisal, and coping. New York: Springer.

Leap-Han, S.B. (2012). Job stress and coping mechanisms among nursing staff in public health services. International Journal of Academic Research in Business and Social Sciences, 2(7), 131-176.

Liu, W. -W., Pan, F. -C., Wen, P. -C., Chen, S. -J., \& Lin, S. -H. (2010). Job stressors and coping mechanisms among emergency department nurses in the Armed Force hospitals of Taiwan. World Academy of Science, Engineering and Technology, 67, 144-151.

Malik, S., \& Noreen, S. (2015). Perceived organizational support as a moderator of affective well-being and occupational stress among teachers. Pakistan Journal of Commerce and Social Sciences, 9(3), 865-874.

Mehta, R.K., \& Singh, I.K. (2015). Stress among nurses working in critical care areas at a tertiary care teaching hospital, Nepal. Journal of Chitwan Medical College, 4(4), 42-48. https://doi.org/10.3126/jcmc.v4i4.11972

Muchhal, A. (2014). Does role clarity explain employee-perceived service quality? International Journal of Service Industry Management, 17(5), 444-473.

Mugenda, O.M., \& Mugenda, A.G. (2009). Research methods, quantitative and qualitative approaches. Nairobi: ACT.

Mulki, J.P., Jaramillo, F., Goad, E.A., \& Pesquera, M.R. (2014). Regulation of emotions, interpersonal conflict, and job performance for salespeople. Journal of Business Research, 68(3), 623-630. https://doi.org/10.1016/j.jbusres.2014.08.009

Naharuddin, N.M., \& Sadegi, M. (2013). Factors of workplace environment that affect employees performance: A case study of Miyazu Malaysia. International Journa of Independent Research and Studies, 2(2), 66-78.

Nwokeocha, S.M. (2015). Academic staff working conditions, organizational commitment and performance of Nigerian universities. Doctoral thesis. Cambridge: Anglia Ruskin University.

Okoyo, G.H., \& Ezejiofor, O. (2013). Incentive packages and employees' attitude to work: A study of selected government parastatals in Ogun State, South-West, Nigeria. International Journal of Research in Business and Social Sciences, 3(1) 63-74.

Olaleye, F.O., \& Arogundade, B.B. (2013). Conflict management strategies of university administrators in South-West Nigeria. Kuwait Chapter of Arabian Journal of Business and Management Review, 2(6), 96-104. https://doi. org/10.12816/0001212
Ramos, A.O., Alés, Y.B., \& Sierra, I.M. (2014). Role stress and work engagement as antecedents of job satisfaction in Spanish workers. Journal of Industrial Engineering and Management. JIEM, 7(1), 360-372.

Rees, T., \& Freeman, L. (2009). Matching social support with stressors: Effects on factors underlying performance in tennis. Psychology of Sport and Exercise, 5 , 319-337.

Rizwan, M., Waseem, A., \& Bukhari, S.A. (2014). Antecedents of job stress and its impact on job performance and job satisfaction. International Journal of Learning and Development, 4, 187e203. https://doi.org/10.5296/ijld.v4i2.6097

Sabherwal, N., Ahuja, D., George, M., \& Handa, A. (2015). A study on occupational stress among faculty members in higher education institutions in Pune. SIMS Journal of Management Research, 1(1), 18-23.

Shah, S.S.A., \& Hasnu, S.A.F. (2013). Effect of job instability on job performance: Banking sector of Pakistan. Journal of Asian Development Studies, 2(1), 3-12.

Sharifah, Z.S.Y., Afiq, I.M., \& Siti, S.D. (2011). Stress and its associated factors amongst ward nurses in a public hospital Kuala Lumpur. Malaysian Journal of Public Health Medicine, 11(1), 78-85.

Shuriquie, S., \& Fitzpatrick, N.K. (2015). Job stress, job performance and organizational commitment in a multinational companies. International Journal of Business and Social Science, 2(20), 20-29.

Shuriquie, M., While, A., \& Fitzpatrick, J. (2015). Nursing work in Jordan: An example of nursing work in the Middle East. Journal of Clinical Nursing, 17(8), 999-1010. https://doi.org/10.1111/j.1365-2702.2007.01973.x

Sims, R.L., \& Sun, P. (2012). Work strain and intention to quit. International Journal of Stress Management, 23(1), 23-43.

Sullivan, G.M. (2011). A primer on the validity of assessment instruments. Journal of Graduate Medical Education, 3(2), 119-120. https://doi.org/10.4300/ JGME-D-11-00075.1

Suwati, M., \& Gagah, E. (2016). Influence of motivation work, career development and cultural organization on the job satisfaction and implications on the performance of employees. Journal of Management, 2(2), 23-29.

Tahir, P.G., ljaz, Z., \& Salma, U. (2014). Impact of working environment on employee's productivity: A case study of banks and insurance companies in Pakistan. European Journal of Business and Management, 7(1), 329-346.

Tearle, P. (2013). Work related stress. European Journal of Business and Social Sciences, 1(10), 73-80.

Truxillo, D.M., Cadiz, D.M., Rineer, J.R., Zaniboni, S., \& Fraccaroli, F. (2012). A lifespan perspective on job design: Fitting the job and the worker to promote job satisfaction, engagement, and performance. Organizational Psychology Review, 2(4), 340-360. https://doi.org/10.1177/2041386612454043

Tsutsumi, A., \& Kawakami, N. (2014). A review of empirical studies on the model of effort-reward imbalance at work: Reducing occupational stress by implementing a new theory. Social Science \& Medicine, 59(11), 2335-2359. https://doi. org/10.1016/j.socscimed.2004.03.030

Uriena, B., Oscab, A., \& Salmonesc, L.G. (2016). Role ambiguity, group cohesion and job satisfaction: A Demands-Resources Model (JD-R) study from Mexico and Spain. Journal of Elsevier España, S.L.U, 11(1), 29-41.

Vanishree, P. (2014). The impact of role ambiguity, role conflict and role overload on job stress in small and medium scale industries. Research Journal of Management Sciences, 3(1), 10-13.

Velnampy, T. (2013). Occupational stress and organizational commitment in private banks: A Sri Lankan experience. European Journal of Business and Management, 5(7), 254-267.

Whiting, A. (2016). Investigating the immediate and long term effects of job stressors on frontline service employees. International Journal of Marketing Research, 28(4), 319-331. https://doi.org/10.1016/j.ijresmar.2011.05.006

World Health Organization. (2008). Health workers for all and all for health workers. Geneva: World Health Report.

Yaşlığlu, M., Karagülle, A.Ö., \& Baran, M. (2014). An empirical research on the relationship between job insecurity, job related stress and job satisfaction in logistics industry. Procedia - Social and Behavioral Sciences, 99, 332-338. https:// doi.org/10.1016/j.sbspro.2013.10.501

Zafar, Q., Ali, A., Hameed, T., llyas, T., \& Younas, H.I. (2015). The influence of job stress on employees performance in Pakistan. American Journal of Social Science Research, 1, 11-13.

Zikmund, W.G., Babin, B.J., Carr, J.C., \& Griffin, M. (2013). Business research methods. LA: Cengage Learning.

Zina. (2017). Nurses embark on nationwide strike. Press Statement. Harare: Zimbabwe Nurses Association. 